\title{
SIGHT RECORD OF DIPPER NEAR EASTEND, SASKATCHEWAN
}

\section{by Elizabeth Cruickshank, 2329 Athol Street, Regina}

Sight records of the Dipper, Cinclus mexicanus, in Saskatchewan were reviewed in the Blue Jay, 16:65, June, 1958. Refarence is made to sightings at Ravenscrag, May 22, 1917, by Spencer Pearse, at the Pearse ranch at Eastend by Pearse and Neil Pratt and by Bob Friel at Farwell Creek. No specific dates are given for the latter records (presumably in the 1930 's or early 1940 's), but it is significart that all these observations were made on the southern slopes of the Cypress Hills.

In the same general area Ruth Baker and I on May 6, 1969 observed one alight on a boulder and then walk into and under the water as it rushed, in flood, over the concrete crossing of the Frenchman (Whitemud) River 10 to 11 miles west of the steel bridge at the town of Eastend. We had driven off the river road, under a railway trestle, leading into Alf Pearse's ranch.

Sharon Haggerty of Regina reports having seen a Dipper a few days later, on May 9, in the Cypress Hills Park. The bird was also seen by Miss Haggerty's companion, who was familiar with Dippers in the mountain streams at Jasper, Alberta.

I returned with Margaret Belcher on June 15 to show the location to her and to Dr. George Ledingham, on our way home from the S.N.H.S. annual field meeting. However, a brief search for the Dipper along the creek was without success.

\section{NINTH ANNUAL MAY BIRD CENSUS, REGINA}

On Saturday, May 17, 38 persons counted a total of 150 species and 7909 individual birds in the Regina area. The total of 150 species is a new record and surpasses by six the previous high of 144 established in 1966 and equaled in 1967. Although we were obviously short of counters to cover the area adequately, it was encouraging to note that included in the total were 10 teen-aged girls. The girls belong to the St. Chad's Science Club and were brought into the field by Lorne Scott, our youth program co-ordinator.

Weather conditions were favorable; extensive cloud cover in the morning was followed by bright sunshine in the afternoon; SE winds gusted to 25 $\mathrm{mph}$, temperatures ranged between $35^{\circ}$ and $65^{\circ}$.

The highlight of this year's count was the discovery by Father Bedard and Greg Bobbitt of a male Prothonotary Warbler; this find constitutes a first for our area and places this eastern warbler well out of his range. It is also worthy of note that a Winter Wren, rarely observed in the area, was seen by George Ledingham.

\section{SPECIES LIST}

(Numbers for May 11, 1968 in parenthesis for comparison)

Horned Grebe, 18 (71) ; Eared Grebe, 62 (66) ; Western Grebe, 24 (41); Pied-billed Grebe, 2 (15); Black-crowned Night Heron, 4 (0); American Bittern, 1 (2); Mute Swan, 5 (2); Whistling Swan, 10 (34); Canada Goose, 340 (305); Mallard, 301 (332); Gadwall, 30 (94); Pintail, 157 (64); Green-winged Teal, 13 (25) Blue-winged Teal, 77 (147); American Widgeon, 52 (175); Shoveler, 77 (70); Redhead, 26 (170); Ring-necked Duck, 6 (2) ; Canvasback, 63 (86) ; Scaup, 130 (355) ; Bufflehead, 7 (11); Ruddy, 34 (43); Hooded Merganser, 1 (0); Sharp-shinned Hawk, 1 (1) ; Red-tailed Hawk, 2 (5); Rough-legged Hawk, 1 (1) Swainson's Hawk, 9 (6); Marsh Hawk, 7 (33) ; Sparrow Hawk, 1 (2) ; Ruffed Grouse, 2 (0); Gray Partridge, 3 (5) ; Virginia Rail, 1 (0); Sora, 7 (8); Coot, 39 (460); Semipalmated Plover, 16 (38); Killdeer, 84 (153) American Golden Plover, 55 (0); Black-bellied Plover, 9 (1): Common Snipe, $1(0)$; Spotted Sandpiper, 22 (22); Solitary Sandpiper, 2 (25); Willet, 22 (55); Greater Yellowlegs, 2 (7): Lesser Yellowlegs, $13 \quad(50)$; Pectoral Sandpiper, 64 (83); Baird's Sandpiper, 78 (46) ; Least Sandpiper, 13 (19) ; Dowitcher, 